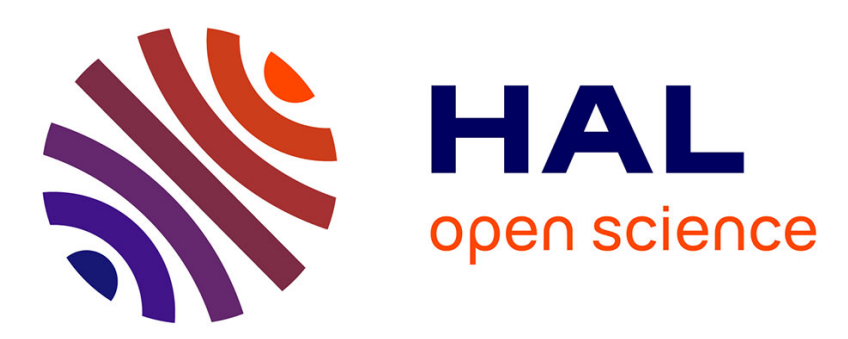

\title{
The social geography of ethnic minorities in metropolitan Paris: a challenge to the French model of social cohesion?
}

\author{
Cédric Audebert
}

\section{To cite this version:}

Cédric Audebert. The social geography of ethnic minorities in metropolitan Paris: a challenge to the French model of social cohesion?. Patterns of Prejudice, 2013, Social Cohesion and Social Change in Europe, 47 (3), pp.309-327. 10.1080/0031322X.2013.814876 . hal-01952179

\section{HAL Id: hal-01952179 https://hal.univ-antilles.fr/hal-01952179}

Submitted on 7 Sep 2021

HAL is a multi-disciplinary open access archive for the deposit and dissemination of scientific research documents, whether they are published or not. The documents may come from teaching and research institutions in France or abroad, or from public or private research centers.
L'archive ouverte pluridisciplinaire HAL, est destinée au dépôt et à la diffusion de documents scientifiques de niveau recherche, publiés ou non, émanant des établissements d'enseignement et de recherche français ou étrangers, des laboratoires publics ou privés. 


\title{
The social geography of ethnic minorities in metropolitan Paris: a challenge to the French model of social cohesion?
}

\author{
Cédric Audebert
}

An original version of this article was published in Patterns of Prejudice, Vol. 47, No. 3, 2013, pp. 309-327.

DOI: $\underline{\text { http://dx.doi.org/10.1080/0031322X.2013.814876 }}$

\begin{abstract}
In order to address the specific social challenges of immigrants and ethnic minorities in the poorest urban neighbourhoods in Paris, new policies of social cohesion have been implemented over the past three decades that focus on place of residence rather than on ethnicity or national origin. The design of a social cohesion policy that deals with socio-geographic inequality rather than with ethnicized populations as such has been a subtle way of addressing the ethnic issue without directly calling into question the postulate of republican universalism. From this perspective, Audebert attempts to understand the role of place and social geography in the formalization of collective identities that have emerged in response to decades of public policies that have been unable to respond to the social, economic and political demands of ethnic minorities. He also attempts to analyse how the French state has relied on social geography as a way to address racial and ethnic issues without directly endowing them with an institutionalized dimension. His hypothesis is that the issue of social cohesion in contemporary France and the way it is dealt with by republican institutions is above all a matter of social geography. The French approach that gives prominence to the urban territorialization of social inequalities over the ethnic categorization approach remains firmly based on republican ideals. Nonetheless, such a policy is innovative in the French context, as it differs from the French traditional assimilationist model and takes into account social and cultural diversity in large metropolitan areas. Audebert's article provides a better understanding of the influence of this integration model on the construction of Otherness. It puts into relief the role of urban geography in the emergence of ethnicity and the design of innovative policy that addresses the issue of cultural diversity.
\end{abstract}

Keywords: ethnic minorities, France, immigration, Paris, social cohesion, social geography, urban geography 
Although immigration has played a key role in French demographics, economy and society since the nineteenth century, it has long been treated as a negligible phenomenon. French social sciences considered the integration of immigrants to be of little interest until the early 1980s when migration was still perceived as a temporary and marginal occurrence, reflecting the dominant perception of immigration by policymakers as an anomaly. ${ }^{1}$ Nonetheless, research on ethnicity, racism and ethnic minorities grew in importance in the $1990 \mathrm{~s},{ }^{2}$ and thereafter has become central to the social sciences. ${ }^{3}$

Over the past decade, the French colonial heritage has emerged as a prominent issue in the analysis of ethnic minorities in contemporary France. In particular, the relationships between France's colonial legacy, the marginalization of ethnic and racial minorities in the national historiography, and collective perceptions of 'identity', have become a major concern. ${ }^{4}$ The geographic concentration of non-European immigrants and their descendants, the formation of ethnic minority groups and the ethnicization of social relations in the banlieues - urban working-class neighbourhoods with heavy concentrations of minority groups - explain why research on postcolonial immigration and social cohesion has increasingly focused on workingclass neighbourhoods of large metropolitan areas.

Recent immigration and social cohesion policies in Europe have been characterized by a reduction of the political and ideological split between assimilationist and multiculturalist societies with the implementation of 'hybrid' policies. In most countries, new immigration legislation has put the emphasis on issues such as language skills and the knowledge of the settlement societies' culture, values and symbols. It has been designed in the context of a changing perception of immigration by public opinion. Such a perception is fostered by the fear of a dilution of those cultural values and beliefs perceived as 'European', and by the crisis of social and political institutions whose purpose is to encourage integration.

Strategies of the social and cultural assimilation of minorities in mainstream society are considered by many governments alongside a respect for ethnic identities. Policies that promote cultural difference are being called into question by a generalized crisis of identity at the nation-state level - a debate that has developed on both sides of the Atlantic ${ }^{5}$ - and by an evolution of perceptions of the Other that conflate second- and third- generation minorities with postcolonial immigrants.

The French integration policy seems to go against this general trend with the implementation of specific measures for particular populations in identified areas that relativize the assimilationist outline. The challenge lies in the institutional acknowledgment of the specific problems encountered by ethnicized populations without awarding them an official status that would depart from the founding principles of the republican model of integration. The design of a social cohesion policy that focuses on socio-geographic inequality rather than on ethnicized populations themselves has been a subtle way of addressing the ethnic issue without directly calling into question the postulate of republican universalism.

From this perspective, I attempt to understand the role of place and social geography in the formalization of collective identities that has emerged in response to decades of public policies that have been unable to respond to the social, economic and political demands of ethnic minorities. I also intend to analyse how the French state has relied on social geography as a way to address racial and ethnic issues without directly endowing them with an institutional dimension. My hypothesis is that the issue of social cohesion in contemporary France and the way it is dealt with by republican institutions is above all a matter of social geography. 
My premises are based on three observations. First, working-class neighbourhoods of large metropolitan areas have remained major areas of settlement for postcolonial immigrants in France. This helps to explain why ethnic minorities are residentially concentrated and overrepresented in these places, which will be referred to as banlieues in my analysis. Second, ethnic minorities in the banlieues are confronted with persistent and specific social and economic problems that partially have to do with their treatment as second-class citizens. As a result, these places crystallize social and identity tensions that call into question the republican model of integration. They also witness the emergence of new forms of social cohesion. Third, in relation to the second point, the banlieues are the main focus of the ambivalent perceptions of the dominant society towards immigrants and minorities. In consequence, they are subjected to specific, territorialized, policies.

\section{Postcolonial immigration and residential geography in metropolitan Paris}

The singularity of the French model of integration lies in its conception of social cohesion. At odds with the multiculturalist approach embraced in countries like the United Kingdom or the Netherlands, this conception promotes universal citizenship and discards the expression of cultural difference in the public sphere as a way to ensure fair treatment for all individuals regardless of their ethnic or geographic background. Accordingly, policies of social cohesion in France have traditionally been based on the republican ideals of assimilation. Throughout the twentieth century, the ideology of social and cultural assimilation of successive waves of immigrants in mainstream society has promoted the vision of a creuset français: a French melting pot. ${ }^{6}$

Nonetheless, increasing social inequality following the economic crisis of the 1970s and 1980s and recent forms of socio-spatial segregation challenged the 'assimilationist' model of integration to such an extent that some scholars have distinguished traditional European immigration from the more recent postcolonial immigration. ${ }^{7}$ The acceptance of the latter in French society has been more problematic, although the cultural and social integration of these immigrants is undeniably a work in progress. ${ }^{8}$ In addition, globalization, neoliberalism and transnational forces have brought about the relative decline of identity as linked to the nation state. Globalization has shaped supranational levels of political decision-making whereas the legitimacy of intra-state regional entities has been reinforced. In post-industrial France, declining universal utopias (such as socialism) in a post-Cold War context have been replaced by other collective references, including ethnic identification. Ethnicity has also been reinforced by the increasing interconnectedness of globalized social, economic and cultural systems.

The universalist and egalitarian French model of incorporation is particularly challenged by the experience of first- and second-generation Caribbean, sub-Saharan and North African minorities. In their everyday life - employment, housing, education and politics, among other spheres - their citizenship is questioned by a restrictive conception of the 'national community' with a recurring resurgence of nativist attitudes. The ambivalent position of second-generation minorities lies in the tension between their full access to political and social rights as French citizens on the one hand, and, on the other, their construction as Others through ethnicization and racialization processes, e.g., differentiation as Blacks or Arabs. Marginalization processes and social inequality are nowhere more apparent than in the northern and northeastern banlieues of metropolitan Paris, where a significant proportion of immigrants and ethnic minorities of African and Caribbean descent have settled. 
In the twentieth century, many successive immigrant waves have responded to the transformation and needs of the French economy. Though most of the flows originated from neighbouring European countries before the Second World War (89 per cent of immigrants in 1946), the source of immigration to France diversified in the second half of the century with the emergence of postcolonial migrations that connected France to its North African and subSaharan African ex-colonies as well as its Caribbean and Indian Ocean overseas departments. The thirty-year boom that followed the war attracted hundreds of thousands of migrant workers in the mining, construction, manufacturing and chemical industries. As the Polish presence irremediably declined and traditional flows from Italy and Spain reached a peak in the 1960s, the share of Maghrebis and sub-Saharan Africans in the immigrant population continuously rose from 3 per cent in 1946 to 43 per cent in 1999. In parallel, the institutional migration of over 200,000 civil servants from the French Caribbean and other overseas departments was organized to meet the needs of the French administration to fill less qualified positions.

The concentration of postcolonial migrant workers in low-paying jobs in the manufacturing sector (car industry, metallurgy, foundries) and in private and public services, along with the role of Paris as a gateway city and France's industrial centre, account for the settlement of the majority of non-European immigrants in the capital. Over the last sixty years, the increasing share of immigrants in the total population of the Paris metropolitan area has kept up with the pace of the growing presence of postcolonial immigrants in France. According to INSEE (Institut National de la Statistique et des Etudes Economiques), almost 39 per cent of immigrants in France were located in this area in 2006. Immigrants make up 17 per cent of the regional population, which is twice the share of the immigrant population at the national level. Not surprisingly, the recent evolution in the origins of immigrants reflects national trends. In metropolitan Paris, between 1999 and 2006, postcolonial migrants made up most of the increase in the immigrant presence, and they now comprise almost half of the 1.95 million foreign-born residents in Paris.

Their socio-economic incorporation, the evolution of urban planning, strategies of public and private institutions as well as French immigration and integration policies are among the main factors that account for the specific residential patterns of postcolonial migrants and their descendants in France. In the postwar boom, North Africans settled in the slums and in deteriorated housing close to the factories in the manufacturing belt in the nearby northwestern suburbs of Paris. Sub-Saharans (especially Malians and Senegalese) settled in immigrant residence blocks (foyers Sonacotra) or in old dilapidated buildings in the city of Paris; they also joined Algerians in the northern working-class suburbs (Saint-Denis, Aubervilliers). In parallel, the authorities initiated the destruction of the slums and the construction of large public housing estates in the suburbs.

The economic crisis of the 1970s and the relative deindustrialization that followed brought many challenges to these immigrant communities in their search for housing. Real estate speculation in the northwestern suburbs and old working-class neighbourhoods of Paris made access to housing more difficult in those areas. As a result, many more African immigrant households moved to the traditional northern working-class suburbs where their presence increased dramatically. In 1974 new immigration legislation restricted the entry of foreign workers and indirectly encouraged family reunification. The growing size of immigrant households and the deterioration of their living conditions in small accommodation gave rise to the search for larger homes.

As a response to this situation, additional programmes of public housing construction were launched in municipalities with a working-class tradition and a strong social heritage. The majority were located in the northern manufacturing belt that included the eastern part of Seine- 
Saint-Denis and adjacent sections of southeastern Val-d'Oise. As a consequence, the share of North African and sub-Saharan immigrant households in public housing has dramatically increased since the 1970s and almost 40 per cent of the population in this area lived in social housing in 2006. This trend has been reinforced by a 1 per cent employers' tax, the so-called ' 1 pour cent patronal', according to which large industrial firms and local public service branches have been granted a social housing quota for the accommodation of their most disadvantaged employees.

\section{The concentration of ethnic minorities in the northeastern belt of metropolitan Paris}

When compared with other foreign-born populations, postcolonial newcomers (namely, North Africans, sub-Saharan Africans and French citizens originating from the overseas departments) display residential patterns that bring out the key role of the northern and northeastern Parisian banlieues. Southern Europeans (Portuguese, Spaniards and Italians) are widely scattered throughout metropolitan Paris, in working-class areas as well as in middle-class suburbs. Southeast Asians and Chinese are over-represented in the 'new towns', especially Marne-laVallée and, to a lesser extent, in Paris's Chinatown. By contrast, most of the immigrants from the Maghreb and sub-Saharan Africa live in the same northern and northeastern sections of Greater Paris as do migrants from the French Caribbean.

Over the years, the presence of postcolonial immigrants and ethnic minorities in this northern section of metropolitan Paris has increased. This can be explained, first, by the low income of the residents related to an average position at the bottom of the socio-professional ladder. The economic recession and the advent of the post-industrial era have hit non-qualified workers and employees the hardest. According to INSEE, more than two out of three immigrant workers from the Maghreb and sub-Saharan Africa are in these socio-professional categories. This partly explains the high unemploy- ment rate of postcolonial migrants ( 22 per cent), more than twice the rate of immigrants from the European Union and French-born people. A study conducted by INSEE in 2007 showed that the average income of African-born householders $(€ 12,670)$ was far lower than the income of European immigrant householders $(€ 18,540)$ or that of native-born householders $(€ 21,680){ }^{9}$ This socio-economic situation limits the residential opportunities of these immigrants and explains the fact that the opportunity for mobility of Africans more often than not involves movement from one working-class neighbourhood to another with similar social and environmental characteristics. ${ }^{10}$

Second, residential mobility from the northern industrial belt to upmarket neighbouring areas is further limited by the reluctance of affluent municipalities to implement social housing policies. In metropolitan Paris, 45 per cent of the 181 municipalities subject to the provision of Article 55 of the Urban Solidarity and Renewal Act were still reluctant to develop social housing during the period 2005-7. ${ }^{11}$ They would rather be fined than abide by a law that required that social housing make up 20 per cent of their housing stock. Most of these municipalities are affluent places adjacent to socially disadvantaged areas and want to maintain 'social homogeneity' by any means. They are also characterized by the smallest non-European immigrant presence in Greater Paris.

Third, the residential mobility of native households and long-term immigrant households that can afford to leave the northern and northeastern corridors and resettle in more affluent areas provides more opportunities for recent immigrants (especially from sub-Saharan Africa and the Maghreb) in working-class neighbourhoods. But, at the same time, in response to the difficulty of attracting native households in these areas, some realtors and public housing institutions resort to discriminatory practices that tend to direct minority households towards 
public housing in specific working-class areas with already high concentrations of immigrants and minority groups. From this perspective, informal ethnic categories - such as 'Black' or 'Arab' minorities v. 'White' or 'native French' - have emerged in contradiction to republican principles.

People born in the French overseas departments - 75 per cent of whom in Paris are from the Caribbean - also fall into this category. ${ }^{12}$ Although they are French citizens, their residential patterns bear a strong resemblance to those of postcolonial immigrants. The dynamics of their settlement is certainly specific when compared with the situation of their foreign-born neighbours, as over half of Caribbean-born French citizens are employed in the public sector. But their employment in less-qualified public positions and, above all, the institutionalization of their access to housing that has accompanied the institutionalization of their migration by the French state - through public housing agencies' strategies of resettlement - account for their strong cohabitation with immigrants from the Maghreb and sub-Saharan Africa. Half of them reside in the social housing projects in the banlieues of Greater Paris that were built at the time of their arrival in the 1960s and the 1970s.

A fourth reason for the increasing presence of North African and sub-Saharan immigrants in this area is related to the socio-demographic characteristics of households. On average, they are younger and have higher fertility rates than other immigrant households who have been in France for a longer time. In addition to transnational social networks and the growing importance of family reunification since the mid-1970s, this partly explains the larger size of Maghrebi and sub-Saharan African households - with an average of 3.7 people - as compared to those of European immigrants, with 2.7 people. ${ }^{13}$ The French census does not provide information on ancestry, which makes it difficult to assess the importance of the second generation of North African or sub-Saharan descent, and makes it impossible to evaluate with statistical precision the presence of ethnic minorities.

However, INSEE data do provide information on children ( 0 -18 years old) living in immigrant families and on their country of birth or nationality. Although this does not include children of immigrants who are above eighteen - which means that a significant share of second-generation French with immigrant backgrounds are not categorized and counted as such - such data give indirect information on their demography and their presence in working-class neighbourhoods. According to the 1999 General Census of the Population, around 3 million children lived in immigrant families in France, half of whom resided in North African and sub-Saharan families. ${ }^{14}$ And, according to the latest Census, immigrants are over-represented in socially disadvantaged neighbourhoods (the so-called zones urbaines sensibles or ZUS), where they make up a quarter of the active population. ${ }^{15}$ This is especially the case in the municipalities of the northern and northeastern banlieues of metropolitan Paris, where they make up 28 per cent of the 1.5 million people residing in the area.

\section{Residential geography and social inequality}

The remarkable concentration of postcolonial migrants - foreign-born newcomers and natives of the overseas departments alike - in the less affluent sections of metropolitan Paris, especially in the northern and northeastern banlieues, is related to the history of their settlement, their ethnic networks and their average low income. Relatively high fertility rates, the young age of the members of the households at the time of their arrival, and family reunification account for the over-representation of second-generation French citizens in these areas. Such residential patterns, which often have to do with strategies of external agents and institutions as much as with the choices of individuals or households themselves, challenge the French model of social 
cohesion. Collective perceptions of urban segmentation tend to associate immigrant clusters with poverty, low standards of education and insecurity. Place then becomes a powerful basis for the categorization of postcolonial populations as 'ethnic minorities' with values and attitudes that are presented as quite different from core national beliefs and norms.

As opposed to national contexts with a multiculturalist approach, such a categorization is not official nor is it aimed at endowing minority groups with specific rights. It has more to do with a collective process of social distancing and marginalization on ethnic and racial grounds, despite the fact that collective identities are not officially recognized. Nationally, postcolonial immigrants from the Maghreb, sub-Saharan Africa and Indochina are more likely to be unemployed than French citizens; and, even for those who do not reside in disadvantaged neighbourhoods, the likelihood of finding a job is 16 per cent lower for postcolonial immigrants and 8 per cent lower for other immigrants than it is for nationals during the initial three-year period on the employment market, after controlling for all factors. ${ }^{16}$ The situation is even worse in disadvantaged areas (ZUS), where the likelihood of getting a job is 39 per cent less for postcolonial immigrants. ${ }^{17}$

Beyond citizenship or immigration status, this inequality of opportunity is also an important issue for the second generation. Nationwide, among urban dwellers under thirty who live in disadvantaged neighbourhoods, the likelihood of getting a stable job is 25 per cent higher for a French citizen whose father was born in France than it is for a French citizen whose father was born in the Maghreb, sub-Saharan Africa or Southeast Asia during the initial three-year period on the employment market, after controlling for all factors. ${ }^{18}$ Place plays a crucial role in such inequality: in French cities, among young adults under thirty in their initial three-year period of activity, the likelihood of getting a stable position is 23 per cent lower for those who live in disadvantaged areas, as shown by the ONZUS report. ${ }^{19}$

In Greater Paris, places with a significant immigrant and second- generation ethnic-minority presence are also those that have to face the most acute social problems. We have identified fifty-three municipalities in the metropolitan area where immigrants make up at least 20 per cent of the local population. Most households from the Maghreb, sub-Saharan Africa, the French Caribbean, Turkey, South Asia and Southeast Asia in Paris have settled in these municipalities. Though ethnic statistics are not available in the French census, a comparison of living conditions in these areas with average living conditions in Greater Paris provides indirect information on the living standards of immigrants and their children. Unemployment (16 per cent) is almost 50 per cent higher than in the metropolitan area as a whole, and the median household income $(€ 13,680)$ is also much lower than the average metropolitan standard $(€ 19,945)$. Furthermore, while these fifty-three municipalities compose only one-fifth of the census tracts in Ile-de-France, they include almost three-quarters of the region's census tracts with median household incomes that are less than half the regional average.

Though interethnic cohabitation is more often than not the norm, different types of immigrant settlement areas are distinguishable wherein ethnic clusters may be identified: the northern and northeastern corridor; the southeastern belt; and peripheral clusters that correspond to the new residential and industrial geography of Ile-de-France after 1968 (such as the creation of 'new towns' like Marne-la-Vallée, Evry and Saint-Quentin-en-Yvelines, or the development of industrial parks like Mantes-la-Jolie and Les Mureaux). The northern and northeastern corridor is the oldest area of immigrant settlement and the largest area of postcolonial minorities' concentration in France. Individuals of North African and sub-Saharan African ancestry (immigrants and their children born in France) are overrepresented and, according to Michèle Tribalat, children of immigrants already constituted a majority of individuals under eighteen in all thirteen core municipalities of this area in $1999 .{ }^{20}$ 
The core area of the northern and northeastern corridor is characterized by a longer history of urbanization and industrialization, and has higher concentrations of immigrants, than the external area of this corridor where immigrant settlement is more recent. In the core area, immigrants make up 30 to 40 per cent of the population of municipalities; in the outer zone, they make up on average 24 per cent of the population. ${ }^{21}$ Thus, these places are generally perceived by conventional wisdom and depicted by the media as ethnic minority areas.

In comparison with other areas of immigrant settlement in metropolitan Paris, the northern and northeastern banlieues - which comprise most of the population of Seine-Saint-Denis and southeastern Val d'Oise - are characterized by higher concentrations of ethnic minorities but also by more working-class people, more poverty and a higher concentration of social housing. Likewise, the average unemployment rate in the thirteen municipalities ( 20 per cent) is twice as high as the metropolitan average of 11 per cent. The average household median income of $€ 10,988$ a year is far lower than that of other immigrant settlement areas (around $€ 14,500$ ) and only half that of metropolitan Paris $(€ 19,945)$.

For this reason, ethnic minorities face a double challenge: they are confronted with the daily difficulties inherent in their disadvantaged social status; and they also have to overcome the stigma attached to their place of residence, as collective perceptions of the dominant society associate the banlieues - especially Seine-Saint-Denis and southeastern Val-d'Oise - with impoverished ethnic enclaves where law and order have broken down.

\section{Conflicting perceptions of the banlieues and new forms of social cohesion}

The geography of social inequality, associated with the spatial concentration of immigrants and ethnic minorities, has led to the French republican debate on the banlieues becoming dominant. This debate is motivated by social, cultural and political challenges faced by the French model of social cohesion. The conflicting views that sustain the debate all consider the banlieues to be testing grounds for the emergence of a new French society. However, their analyses of the implications of such a transformation of French society notably differ.

On the one hand, supporters of the conservative line - including the previous right-wing government (2007-12), ${ }^{22}$ and some of the mainstream media and intellectuals - are worried about cultural change and social issues related to immigration and the increasing presence of ethnic minorities in France. Though they acknowledge that immigration has been a structural phenomenon in France for over a century, they are concerned by the increasing importance of extra-European inflows, which they perceive as a threat to the social cohesion of the nation. They look on the banlieues as a breeding ground for insecurity and the dilution of an imagined 'French identity' based on Christianity, European ancestry and Latin heritage. Islamic and animist traditions brought by immigrants to Ile-de-France are particularly targeted in such arguments, according to which such traditions are incompatible with 'French values'. ${ }^{23}$ From this point of view, emergent struggles in working-class Parisian suburbs for social equity, cultural and religious expression, and better political representation are associated with the 'expression of difference' in public space, and considered a major issue, as shown by current debates on the chador or on polygamy. Likewise, areas with a strong presence of ethnic minorities are also seen as channels for the importation of geopolitical tensions and international conflicts, such as the Israeli-Palestinian one.

On the other hand, insiders see the banlieues as spatial symbols of the failure of past integration policies. ${ }^{24}$ Therefore they see them as places of opportunities for innovative forms of collective mobilization and social cohesion that are likely to renew the French model of integration, whose republican principles have never been fully implemented. Inhabitants of the banlieues 
develop an alternative vision of social cohesion as a result of their experience of social marginalization and political invisibility. New forms of social cohesion have emerged at the local level, ${ }^{25}$ in multiethnic working-class suburbs, where citizenship is more and more called into question by other identity markers (ethnicity, 'race' and religion). Such trends are the consequence of representations by the dominant society that ethnicize and stigmatize the banlieues, as well as the outcome of emerging collective identities of second- and thirdgeneration minority citizens themselves. In this process, political mobilization of minorities in France has played a key role, and reveals a combination of ethnicization and racialization processes. The external construction of an identity based on skin colour and perceived 'cultural' attributes is internalized by ethnic minorities and partially explains the emergence of ethnicity in the formalization of collective solidarities in these neighbourhoods. ${ }^{26}$

The social and geographical marginalization of the ethnicized populations in the banlieues has been reinforced by their limited political representation and visibility in public space, and the weak coverage given to their specific problems in the media. In this context, new forms of social cohesion that emerge in the socially disadvantaged neighbourhoods of metropolitan Paris aim to give them more visibility in the mainstream media and the political arena so that policymakers pay more attention to their specific issues. The increasing mobilization of ethnic minorities in Paris over the last ten years has been characterized by diverse forms depending on the objectives and the social background of the initiators.

The end of the 1990s witnessed the emergence of political claim-making by postcolonial ethnic minorities - especially from the Caribbean and sub-Saharan Africa - concerning three main issues: the representation of minorities in the media, the incorporation of their heritage in the national historiography and the economic empowerment of highly qualified minorities that are disproportionately stricken by unemployment. The lobbies Club Averroès (including almost 400 professionals) and Collectif Egalité were created in 1997 and 1998, respectively, in order to promote ethnic diversity in the media. Later on, in 2004, Club XXIème siècle was established by minority business leaders and senior officials in order to improve the economic image of socially disadvantaged neighbourhoods and to promote young entrepreneurs from the banlieues through the development of professional networks.

In a postcolonial context, other forms of social cohesion in the banlieues emerged in relation to the history of slavery and colonization, and the acknowledgement of the contribution of the former colonies and overseas territories to France's historical construction and economic prosperity. This campaign was led by French Giuana's deputy Christiane Taubira, who was the driving force behind the 2001 law that recognized slavery and the Atlantic slave trade as crimes against humanity. Though she was criticized and accused of divisiveness by conservative members of the French parliament, ${ }^{27}$ she gained sympathy and strong support from Antilleans, French Guianese and other minority groups. In spite of her low score of 2.32 per cent in the 2002 French presidential election, her left-wing candidacy revealed for the first time the emergence of an ethnic vote based in the banlieues, a fact that went unnoticed in the mainstream media and academia.

Interestingly enough, the geography of Taubira's vote was consistent with the residential patterns of black groups, especially the Caribbean minority. Thus, 28.6 per cent of Taubira's votes in metropolitan Paris were cast in the fifty-three municipalities with the largest postcolonial immigrant and minority presence in the metropolis, although the total electorate in these areas made up only 18.39 per cent of the regional electorate. The constituencies with the highest residential concentrations of Caribbean-born people were also the ones that recorded the strongest mobilization for Taubira: between 8 per cent and 11.5 per cent of the vote (three to five times her score at the national level). Never before had the relevance of 
ethnic geography in voting patterns been better demonstrated than in the 2002 presidential election, as Taubira's candidacy offered a unique opportunity for specific minority issues to be voiced in the republican debate. ${ }^{28}$

Such organized initiatives mainly came from the educated middle-class minorities (professionals, journalists, elected officials) whose social networks served as bridges between multiethnic banlieues and mainstream politics. Nonetheless, in the context of the deterioration of living conditions (including relations between ethnicized populations and the police) in working-class neighbourhoods and widespread distrust and defiance towards the state and its institutions, the year 2005 was a turning-point in the territorialized expression of dissatisfaction with the way the government was dealing with working-class suburbs. Following the death of two teenagers chased by the police and the latter's forceful intervention in front of a mosque in October 2005, unprecedented riots erupted in the banlieues. Unlike previous forms of mobilization, the uprising was spontaneous, without leadership, and came from the most precarious segments of the working-class suburbs' minority groups. Social exclusion was the common ground that motivated the riots that occurred in hundreds of disadvantaged neighbourhoods at the same time, without coordination between them. Symbolic places such as schools, libraries, city halls and businesses were targeted as well as police stations. Nine thousand cars were burned and the property damage was estimated at over $€ 200$ million.

With the 2005 urban riots, ethnic geography had irrupted in the French republican debate. The unrest started on 27 October in Clichy-sous-Bois, the most disadvantaged and marginalized part of Seine-Saint-Denis. Within days, it spread out throughout the northeastern belt of Greater Paris (Montfermeil, Aulnay, Sevran, Blanc-Mesnil, Bondy, Bobigny), which remained the epicentre of the riots for twenty-one days. One week after the unrest started, it acquired a national dimension: it culminated on 7 November with 274 hot spots throughout the nation. The next day, a state of emergency was declared and a curfew imposed in many areas. As a direct consequence of the riots, a new step towards the visibility and empowerment of workingclass suburbs was taken with an unprecedented wave of registration on the electoral roll in the banlieues, following a call from local civic associations. The government also responded to this unprecedented crisis with the design of new social cohesion policies that were overtly aimed at the banlieues.

\section{The territorialization of social cohesion policies in Greater Paris: promise and pitfalls}

In order to address the specific social challenges of immigrants and ethnic minorities in the poorest urban neighbourhoods, new policies of social cohesion have been implemented that focus on place of residence rather than on ethnicity or national origin. The French approach that gives prominence to the urban territorialization of social inequalities over the institutionalization of race and ethnicity remains firmly based on republican ideals. Nonetheless, such a policy is innovative in the French context, as it differs from the traditional French assimilationist model and takes into account social and cultural diversity in large metropolitan areas. While ethnic minority groups are not officially targeted as beneficiaries of such projects, recent policies of urban cohesion aim at addressing the needs of areas with high concentrations of immigrants and minorities.

Expanding on isolated policies of social cohesion that had previously been experiments at the local level in specific locations, the 1996 Urban Stimulation Act paved the way for the territorialization of social cohesion policies in France. ${ }^{29}$ This legislation identified three types of disadvantaged areas. First, 751 neighbourhoods were identified as 'sensitive urban areas' (zones urbaines sensibles or ZUS) on the basis of many criteria, including the presence of high- 
rise estates, deteriorated housing and isolation from the major centres of economic activity. Second, 416 'urban renewal areas' (zones de renouvellement urbain or ZRU) were identified among the ZUS, by means of criteria that indicated the low social standing of their residents, including unemployment, the percentage of people under twenty-five and the percentage of young adults without diplomas. Third, among the ZRU, 100 'urban free trade zones' (zones franches urbaines), with over 8,500 residents and characterized by economic decay, were delineated with the aim of boosting local economic activities.

In parallel, experimental policies against discrimination were launched at the local level in 2001. From the beginning, their territorial dimension was promoted in order to encourage joint action between municipalities, the regional authority and government agencies in specific locations. Following the 2005 riots, social activism and anti-discrimination policies were further territorialized with the implementation of the social cohesion urban contracts (contrats urbains de cohésion sociale or CUCS) during the 2007-10 period. They gave top priority to employment issues and have involved an increasing number of actors over time (businesses, state employment agencies, municipalities, neighbourhood associations, unions). The social activism of young jobseekers from working-class suburbs is encouraged through businesssponsored training and coaching programmes as well as employment forums. The ultimate goal is to develop self-esteem and to improve the image of ethnic minority jobseekers from the banlieues in the employment market.

In the working-class suburbs of Greater Paris with high concentrations of immigrants and ethnic minorities, three types of areas with specific social cohesion issues can be identified:

1. Traditional working-class areas that have been seriously hit by de-industrialization and with the highest concentrations of economically precarious immigrants and ethnic minorities: core area of the northern and northeastern corridor of metropolitan Paris and the adjacent northeastern section of the City of Paris (these areas would best correspond to the Anglo-Saxon concept of the inner city and would require the massive and longterm intervention of authorities and the private sector to check their deterioration).

2. Large impoverished areas in which social issues would require the combined intervention of local, regional and national authorities with an action plan at the regional level rather than at the local one: outer area of the northern and northeastern corridor of metropolitan Paris, including Sevran, Gonesse, Bondy etc., and pockets of the southeastern suburbs identified in our study.

3. Pockets of poverty surrounded by well-off suburbs in the outer suburbian ring, in peripheries characterized by strong socio-spatial inequality: Clichy-sousBois/Montfermeil, Mantes-la-Jolie, Grigny, les Mureaux/ Carrières-sous-Poissy, and 'new towns' with similar social cohesion issues, such as Trappes and Evry/Corbeil.

Regional authorities have implemented policies that have addressed this socio-geographical diversity. A programme of 'territorial affirmative action' (discrimination territoriale positive), as labelled by its promoters, has been set up in order to reduce social and economic inequality between the ZUS and their immediate geographical environment. Nonetheless, the case of the northern and northeastern banlieues demonstrates that urban renewal policies have had ambivalent effects so far. These areas have the highest concentration of social housing in Greater Paris, and a third of social housing projects have been identified by authorities as priority areas for urban renewal, the highest proportion in France. Paradoxically, such policies have reinforced socio-spatial inequality and segregation. Whereas public policies of urban renewal in other parts of metropolitan Paris (Yvelines, Seine-et- Marne, Val-de-Marne) have brought about the scattering of social housing and thereby reduced spatial discrepancies, they 
have had the opposite effect in the northern and northeastern banlieues. Renewal has replaced social housing by social housing, and disadvantaged families that have moved to other social housing projects in adjacent areas have been replaced by households with similar social characteristics. As a result, rather than promoting a greater social mix of housing (as observed elsewhere), such policies have furthered processes of social ghettoization. Today, they are one of the key causal factors in the increasing concentration of immigrants and ethnic minorities in this section of Greater Paris.

\section{The French model of social cohesion: a socio-territorial approach}

Social geography has been a crucial element in explaining the ethnicization of social relations in metropolitan Paris and, more generally, in France. The concentration of a consistent proportion of socially disadvantaged immigrants from former French colonies and other developing countries (such as Turkey, Sri Lanka or India) in the northeastern belt and other Parisian working-class suburbs has made the question of social inequality a territorial issue. Alongside the many social challenges the population of the banlieues has to face in terms of poverty, housing, employment and political representation, a stigma is also attached to residing in such places that reinforces social distance and discriminatory practices. However, the interplay between social distance and spatial segmentation is a two-way process in response to which diverse and original forms of collective mobilization have emerged. An increasing presence in the media, in professional associations and even in electoral battles brings a new audience and visibility to working-class minorities and their settlement areas. Such mobilizations seldom play the ethnic card as such - at least not in the public sphere - but rather tend to highlight social as well as territorial inequality.

Following a highly polarizing debate on the relevance of institutionalizing ethnic and racial issues (through ethnic statistics and affirmative action), the French state has been confronted with an unprecedented challenge: to acknowledge and deal with the specific problems of ethnic minorities without calling into question the postulate of republican universalism. Over the last decade, a way to meet this challenge has been to put the emphasis on issues of social geography as the foundation for social cohesion policies.

As a result, the banlieues have been the target of greater attention from national as well as local authorities. An institutional typology of working-class neighbourhoods has been designed (ZUS, ZRU, ZFU etc.) in relation to the nature and scope of the policies to be implemented. In our study of metropolitan Paris, we have identified three types of disadvantaged areas with specific social challenges related to their urbanity, their economic and social history, their respective role as immigrant gateways, the social profile and level of poverty of their population, and their relative connection (proximity) or isolation (distance) to other parts of the metropolis in general. Beyond broad institutional designations and categories, social cohesion policies should take into account the specific characteristics that have to do with the history, sociology and geography of the banlieues at the very local level.

Moreover, general social cohesion policies have had perverse effects in the most disadvantaged areas: the construction of social housing has essentially taken place in locations that are adjacent to areas with the largest concentration of social housing. Empirical observation shows that the cities that welcome social housing are those with an already significantly disadvantaged population. This residential dynamics accounts for the spatial extension of impoverished areas in the northeastern belt and their ghettoization, rather than the diffusion of social mixing throughout the metropolitan area. Such policies also have been difficult to implement because of the reluctance of many municipalities to abide by republican principles 
of solidarity and equality. As a matter of fact, out of the 166 municipalities in Ile-de-France that have been required to meet the objective of 20 per cent social housing by the Urban Solidarity and Renewal Act in the 2008-10 period, only ten had done so by 1 January 2010 . The strongest resistance is observed in wealthy municipalities located in the vicinity of the northern and northeastern belts (such as Le Raincy or Neuilly-sur-Seine).

In sum, the French model of social cohesion is reluctant to accept the expression of collective identities in the public space, as the republican social contract is grounded on the relationship between the state and the individual citizen. Thus ethnic identities are not acknowledged as such.

Nonetheless, the geographic concentration of postcolonial immigrant populations and their descendants in some of the most socially disadvantaged areas of metropolitan Paris poses a problem for the French republican model: socio-economic issues combine with ethnic issues to accentuate the socio-spatial segmentation of the city. In parallel, ethnic residential concentration has given rise to the emergence of collective identities partially based on ethnicity and religion. In this context, the French state has designed a social cohesion policy that has integrated the segmented social geography of metropolitan Paris as a way to address the ethnic question without directly institutionalizing it. In this respect, the social geography of ethnic minorities in this city has long been a challenge to national and local authorities with regard to the design of social cohesion policies. But it has also provided a means to meet this challenge within the republican framework.

\section{Notes}

1 In the 1970s, social scientists were above all concerned by the living conditions of immigrants (such as housing), and the economic dimension and institutional management of migration by the state, rather than by integration issues as such. For early sources, see Gérard Heliot, 'Le logement des travailleurs immigrés', Espaces et Sociétés, no.4, December 1971; Sylvie Arditti, Sonia Roger-Fayman, Bernadette Roussille and Simon Wuhl (eds), Etude sur l'habitat insalubre: le logement des travailleurs immigre s (Paris: Ministère de l'aménagement du territoire, de l'équipement et des transports 1974); Monique Hervo and Marie-Ange Charras, Bidonvilles: l'enlisement (Paris: Maspero 1971).

2 François Dubet and Didier Lapeyronnie, Les Quartiers d'exil (Paris: Seuil 1992); Pierre-André Taguieff (ed.), Face au racisme: analyses, hypothèses, perspectives (Paris: Seuil 1993); Michel Wieviorka, La France raciste (Paris: Seuil 1992).

3 Philippe Poutignat and Jocelyne Streiff-Fénart, Théories de l'ethnicité [1995] (Paris: Presses Universitaires de France 2008); Sophie Body-Gendrot, Les Villes face à l'insécurité: des ghettos américains aux banlieues françaises (Paris: Bayard 1998); Véronique De Rudder, Christian Poiret and François Vourc'h, L'Inégalité raciste: l'universalité républicaine a' l'épreuve (Paris: Presses Universitaires de France 2000); Patrick Simon, 'Les statistiques, les sciences sociales françaises et les rapports sociaux ethniques et de "race", Revue franc aise de sociologie, vol. 49, no. 1, 2008, 153-62; Didier Fassin and Eric Fassin (eds), De la question sociale à la question raciale? Représenter la société franc aise (Paris: La Découverte 2009).

4 Pascal Blanchard, Nicolas Bancel and Sandrine Lemaire (eds), La Fracture coloniale: la société franc aise au prisme de l'héritage colonial (Paris: La Découverte 2005); Patrick Weil and Stéphane Dufoix (eds), L'Esclavage, la colonisation, et après ... (Paris: Presses Universitaires de France 2005).

5 Roger Waldinger, 'Unacceptable realities: public opinion and the challenge of immigration in a Franco-American comparison', in Cédric Audebert and Mohamed Kamel Doraï (eds), Migration in a Globalised World: New Research Issues and Prospects (Amsterdam: Amsterdam University Press 2010), 41-61.

6 Gérard Noiriel, Le Creuset français: histoire de l'immigration XIXe-XXe siècle [1988] (Paris: Seuil 2006).

7 Postcolonial immigration in France refers to contemporary non-white immigration from the former French colonies of the Maghreb, western and central Africa, Indochina and the so-called 'DOM-TOM' (French overseas departments and territories) during the reconstruction period. In the context of labour shortages in transportation, construction, manufacturing, mining and low-paid services, the French state encouraged such flows through bilateral agreements with its former colonies and other institutional frameworks, such as the Bureau des migrations intéressant les travailleurs des départements d'outre-mer. 
8 Blanchard, Bancel and Lemaire (eds), La Fracture coloniale; Emmanuel Todd, Le Destin des immigrés: assimilation et ségrégation dans les démocraties occidentales [1994] (Paris: Seuil 1997).

9 Philippe Lombardo and Jérôme Pujol, 'Niveau de vie et pauvreté des immigrés en 2007', in Les Revenus et le patrimoine des ménages: Edition 2010 (Paris: INSEE 2010), 37-44.

10 Jean-Louis Pan Ke Shon, 'The ambivalent nature of ethnic segregation in France's disadvantaged neighbourhoods', Urban Studies, vol. 47, no. 8, 2010, 1603-23.

11 Loi relative à la solidarité et au renouvellement urbains (loi no. 2000-1208, 13 December 2000).

12 The French overseas departments (Martinique, Guadeloupe, Guyane and Réunion) are ex-colonies that were fully integrated into the politico-institutional system of the mainland in 1946 under the regime of départementalisation. Mayotte recently became the fifth French overseas department.

13 INSEE, 'Résultats du recensement de la population 1999', available on the INSEE website at www.recensement1999.insee.fr (viewed 14 May 2013).

14 Ibid.

15 Mariette Sagot, Corinne De Berny, Brigitte Guigou, Pascale Leroi and Olivier Mandon, Les Jeunes issus de l'immigration: politiques et bonnes pratiques en matière de formation et d'insertion (Paris: Institut d'aménagement et d'urbanisme de la région Ile-de-France 2010), 15.

16 ONZUS (Observatoire national des zones urbaines sensibles), Rapport 2009 (Paris: Les Editions du CIV 2009), 268; see also Cris Beauchemin, Christelle Hamel and Patrick Simon (eds), Trajectoires et Origines: enquête sur la diversité des populations en France, Documents de Travail 168 (Paris: Institut national d'études démographiques 2010), 145.

17 ONZUS, Rapport 2009.

18 Ibid.; see also Beauchemin, Hamel and Simon (eds), Trajectoires et Origines.

19 Ibid.

20 Michèle Tribalat, 'Les concentrations ethniques en France', Agir, no. 29, January 2007, available on the Société de Stratégie website at www.societe-de-strategie.asso.fr/pdf/ agir28txt4.pdf (viewed 14 May 2013).

21 Personal calculations based on the 2006 General Census of the Population; see INSEE, 'Résultats du recensement de la population : 2006', available on the INSEE website at www.recensement-2006.insee.fr (viewed 31 May 2013).

22 The current government has adopted a more relaxed position on immigration and social cohesion issues.

23 Among other examples, a journalist in a prominent French newspaper expressed the view that 'for French people, dialogue between cultures was similar to counter-colonisation, as in some geographic spaces, a culture was developing that was different from theirs' (ça se dispute, broadcast on i-Télé, 8 January 2011). Translations from the French are by the author unless otherwise stated.

24 By 'insiders', I refer to the inhabitants of the banlieues as well as other local actors such as cultural associations and social workers.

25 Such as media lobbies, minority business organizations or new forms of religious proselytism (Christian and Muslim).

26 Such solidarities may be formalized in various ways, including civic action that encourages voting, music and entertainment production and non-profit cultural associations.

27 By emphasizing this painful dimension of Afro-Caribbean history and the responsibility of France, her struggle for the recognition of slavery as a crime against humanity was interpreted by a fraction of the right wing as a 'memorial law' that could potentially provoke conflict and division in French society. 
28 Interestingly, it was the first and only time a candidacy has been able to mobilize ethnic voting to such an extent in a French presidential election. Nothing similar has occurred in the last two presidential elections.

29 Loi relative a` la mise en oeuvre du pacte de relance pour la ville (loi no. 96-987, 14 November 1996). 